\title{
PENINGKATAN AKSENTUASI VISUAL KORIDOR PUBLIK KAWASAN BERSEJARAH PUSAT KOTA LAMA BANDA ACEH
}

\author{
Indah Keumala \\ Magister Arsitektur, Program Pascasarjana, Universitas Katolik Parahyangan \\ Jl. Merdeka no. 30, Bandung, Jawa Barat \\ Email: indah.keumala87@gmail.com
}

\begin{abstract}
Abstrak
Kawasan pusat kota lama Banda Aceh menyimpan nilai sejarah yang tinggi, terbukti dengan banyaknya peninggalan-peninggalan bersejarah yang masih bertahan sebagai objek bersejarah di kawasan ini. Keberadaan artefak-artefak kuno ini dapat melengkapi riwayat sejarah serta menjadi bukti otentik identitas Kota Banda Aceh. Kawasan pusat Kota Banda Aceh membutuhkan ruang-ruang publik yang menarik agar eksistensi aset-aset bersejarah tersebut dapat semakin menonjol sebagai sebuah elemen daya tarik kawasan bersejarah ini. Penelitian ini bertujuan untuk memperkuat identitas kawasan pusat Kota Banda Aceh melalui suatu konsep desain arsitektur di suatu koridor publik potensial yang selama ini belum termanfaatkan secara optimal. Gagasannya adalah dengan merangkai ruang-ruang bersejarah di koridor ini agar dapat lebih mudah dan nyaman untuk diakses oleh para pejalan kaki. Penelitian ini dilakukan dengan melakukan perekaman image visual ruang terbuka pada kawasan koridor publik untuk menangkap gambaran visual dan mengetahui kualitas fisik ruang-ruang publik di lokasi tersebut. Peningkatan aksentuasi visual pada koridor publik kawasan pusat Kota Banda Aceh dapat membentuk sekuens visual yang memberikan pengalaman ruang yang berbeda-beda. Pengalaman ruang ini muncul dari fase-fase ruang bertema sejarah kota yang didukung oleh tampilan elemen-elemen ruang yang relevan dengan nilai sejarah. Kunci keberhasilan dalam perkuatan identitas pada koridor ini adalah pemilihan desain elemen-elemen ruang yang tepat, sesuai dengan karakter ruang yang dapat mewakili nilai-nilai dan identitas sejarah kawasan tersebut.
\end{abstract}

Kata kunci: ruang publik, aksentuasi visual, linkage, kawasan pusat kota bersejarah

\begin{abstract}
Title: Improvement of Visual Accentivation Public Corridors the Old Downtown area of Banda Aceh

The old downtown area of Banda Aceh holds high historical value, as evidenced by the many historic relics that still survive as a historic object in the region. The existence of these ancient artifacts can complement the historical narrative as well as the authentic proof of the identity of the city of Banda Aceh. The central area of Banda Aceh requires interesting public spaces to make the existence of these historic assets more prominent as an element of the attraction of this historic area. This study aims to strengthen the identity of the downtown area of Banda Aceh through an architectural design concept in a potential public corridor that has not been optimally utilized. The idea is to assemble historic spaces in this corridor to make it easier and convenient for pedestrians to access. This research is done by recording visual image of open space in public corridor area to capture visual picture and to know physical quality of public spaces in the location. Increased visual accentuation in the public corridors of the downtown area of Banda Aceh can form visual sequences that provide different spatial experiences. The experience of this space arises from the historical space-themed space phases supported by the gradual display of space elements. The key to success in strengthening the identity of
\end{abstract}


this corridor is the selection of the design of appropriate elements of space, in accordance with the character of space that can represent the values and historical identity of the region.

Keywords: public space, visual accents, linkage, historic downtown area

\section{Pendahuluan}

Kawasan pusat kota lama Banda Aceh telah terbentuk sejak abad ke-17, yakni dengan dijadikannya lokasi ini sebagai pusat kerajaan Aceh. Berdasarkan peta kuno, terlihat bahwa pola ruang pusat kerajaan ini terdiri dari Masjid, Keraton, Pasar, Alun-alun, Taman Sari (Bustanussalatin) dan jalur transportasi berupa sungai. Kejayaan kerajaan Aceh pada masa kepemimpinan Sultan Iskandar Muda merupakan memori sejarah yang menjadi kebanggaan bagi masyarakat Aceh hingga saat ini. Peninggalan-peninggalan bersejarah yang ada di kota ini merupakan aset pusaka yang berharga bagi jati diri kota. (Arif 2008)

Masjid Raya Baiturrahman merupakan salah satu bangunan bersejarah penting yang terletak di kawasan pusat kota lama ini. Bangunan ini begitu populer dengan bentuk arsitekturnya yang bernilai seni tinggi, hingga menjadi landmark Kota Banda Aceh. Dalam perjalanan sejarahnya, Masjid Baiturrahman bukanlah suatu objek bangunan yang berdiri sendiri, melainkan terhubung dengan fungsi-fungsi lain di dalam kota kesultanan sehingga membentuk sebuah peradaban kota yang utuh. Artefakartefak bersejarah lainnya masih dapat dilihat wujud fisiknya di dalam kawasan pusat kota lama ini. Seperti bangunan Gunongan, Pinto Khop dan makammakam Raja, meski saat ini keberadaan artefak-artefak tersebut terpencarpencar. Keberadaan artefak-artefak kuno ini dapat melengkapi riwayat sejarah serta menjadi bukti otentik identitas Kota Banda Aceh.

Seiring berjalannya waktu, kawasan pusat kota lama ini mengalami perubahan-perubahan fisik yang cukup signifikan yang terjadi sesuai dengan perkembangan sejarahnya. Baik perkembangan yang terjadi pada masa kolonial Belanda yang cukup banyak mengubah struktur ruang tatanan fisik ruang kota. Pada masa setelah kemerdekaan, kawasan pusat kota lama Banda Aceh menjadi lokasi ibukota.

Pertumbuhan fisik di kawasan pusat kota memang tidak dapat dihindari mengingat fungsinya sebagai pelayan publik utama di dalam sebuah kota. Sebagai suatu kota yang memiliki nilai-nilai historis yang luhur, peninggalan-peninggalan pusaka tersebut semestinya dapat dilindungi keberadaannya dengan memperhatikan desain tata ruang di dalam kawasan kota tersebut. Semangat melestarikan dan menghubungkan kembali aset-aset pusaka kota di dalam suatu kawasan heritage yang kuat merupakan hal yang perlu dilakukan untuk menjaga eksistensi identitas Kota Banda Aceh ini. Aksentuasi visual merupakan upaya kreatif yang dapat dilakukan oleh perancang kota (arsitek/ urban designer) guna membentuk kawasan kota menjadi lebih menarik dan bermakna. Desain aksentuasi visual sangat penting untuk diterapkan khususnya pada kota-kota bersejarah, guna mengangkat potensipotensi bersejarah di dalam kawasan kota agar eksistensinya tetap terjaga dan terpelihara. Aksentuasi visual juga dapat membentuk ciri khas kota agar memiliki 
keunikan tersendiri yang berbeda dari kota-kota lainnya.

Upaya peningkatan aksentuasi visual titik-titik bersejarah di kawasan pusat kota Banda Aceh sudah banyak yang dibuat., seperti pengolahan fasad pada bangunan pasar Aceh, pengolahan lansekap di Taman Putroe Phang, penambahan pelataran di situs Pinto Khop (Gambar 1), penambahan bangunan entrance di Taman Sari serta renovasi lansekap di Masjid Raya Baiturrahman. Pengolahan ruang yang telah dilakukan lebih banyak untuk pembentukan aksentuasi visual pada node-node publik setempat, namun belum tercipta kesinambungan antara ruang-ruang bersejarah tersebut pada kawasan ini. Pemberian aksentuasi visual pada titik-titik bersejarah ini merupakan upaya yang tepat untuk melestarikan aset-aset pusaka kota.

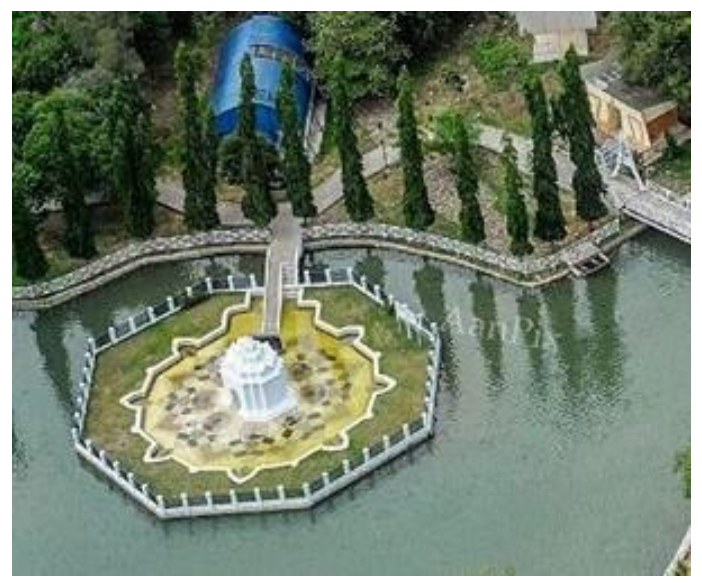

Gambar 1. Pelataran pinto khop

Sumber: www.tripadvisor.com, 2017

Studi ini dilakkan untuk menunjukan bahwa desain aksentuasi visual yang juga dapat dicapai dengan menciptakan sekuen visual yang memberikan pengalaman ruang di dalam kawasan kota secara berkesinambungan dengan merangkai ruang-ruang bersejarah tersebut.

Koridor ruang publik dipilih karena ruang publik memiliki sifat yang sesuai untuk digunakan sebagai tempat untuk memaknai ruang. Pada ruang publik, manusia dapat lebih leluasa untuk mengapresiasi lingkungannya. Selain itu, perancangan koridor publik juga merupakan upaya meningkatkan fungsi ruang di kawasan pusat Kota Banda Aceh agar memiliki suatu jalur pedestrian yang aman, nyaman dan terhubung secara menerus.

Perancangan aksentuasi visual melalui sekuen ruang diharapkan dapat membentuk image ruang bersejarah secara lebih menarik dan utuh.

Pembentukan sekuen visual pada koridor publik perlu dilengkapi dengan pemahaman sejarah kota yang baik, agar pensuasanaan ruang dapat mendukung perkuatan karakter dan identitas kawasan yang tepat. Pembentukan sekuens juga membutuhkan tampilan-tampilan ruang yang bervariasi agar tercipta pengalaman ruang yang menarik. Maka, penelitian ini mempertanyakan tentang prinsip desain bagaimana yang dapat diterapkan pada elemen-elemen ruang tersebut guna memperoleh tampilan yang dapat memperkuat identitas kota.

\section{Metode}

Metode penelitian dilakukan dengan pendekatan kualitatif, antara lain studi literatur mengenai sejarah di kawasan pusat Kota Banda Aceh, membaca pola ruang Kota Banda Aceh dari masa ke masa serta melakukan perekaman image visual ruang terbuka eksisting pada kawasan pusat kota untuk menangkap gambaran sekuen visual dan mengetahui 
kualitas fisik ruang-ruang publik di kawasan pusat kota ini.

Observasi lapangan berguna untuk memantau jarak-jarak antar titik bersejarah serta aksesibilitas publik yang ada, yang ditinjau dari sudut pandang skala manusia. Dari observasi lapangan ditentukan ruang-ruang bersejarah potensial, antara lain zona Sungai, komplek Masjid Raya, Taman Sari dan Taman Putroe Phang sebagai ruang lingkup pembahasan pada penelitian ini. Lokasi ini dipilih karena merupakan zona ruang terbuka publik yang saling berdekatan sehingga memungkinkan untuk dihubungkan secara fisik maupun visual.

Analisis yang dilakukan dengan cara memberikan argumentasi deskriptif mengenai elemen-elemen kota yang membentuk tiap-tiap zona ruang publik tersebut. Elemen-elemen kota yang dimaksud antara lain konfigurasi massa bangunan, vegetasi, street furniture, area parkir, jalur pedestrian, jalur sepeda, jalur kendaraan dan lain-lain. Untuk memperjelas hasil pembahasan, visualisasi rangkaian alur koridor ruang publik ini akan ditampilkan melalui video animasi.

\section{Pembahasan}

Kawasan pusat kota merupakan area yang paling penting untuk menunjukkan image dan identitas sebuah kota. Identitas atau karakter sebuah kota biasanya terbentuk dari potensi ruang dan ke-khas-an tersendiri yang dimiliki oleh kota tersebut. Biasanya, elemenelemen bersejarah selalu menjadi lambang atau simbol yang dimunculkan sebagai identitas sebuah kota. Begitu pula dengan pola pengaturan tatanan ruangnya, terdapat berbagai macam teknik penataan ruang yang menarik dengan memberikan penambahan aksentuasi-aksentuasi visual pada objekobjek tertentu, seperti membentuk bingkai-bingkai arsitektur (vista), membuat sekuen visual, mengatur pola tatanan lansekap, penataan pencahayaan buatan, dekorasi pola lantai, pemilihan material dan model-model elemen ruang pembentuk suasana ruang guna menarik minat publik untuk berkunjung dan menikmati lingkungan pusat kota.

Secara morfologis, kondisi fisik kawasan pusat kota Banda Aceh memiliki kondisi tapak yang relatif datar (rata). Titik terendah pada kawasan ini berada pada zona sungai yang memiliki perbedaan ketinggian muka air tidak lebih dari 3 $5 \mathrm{~m}$ terhadap permukaan tanah (daratan). Kondisi tapak yang cenderung rata membuat keberadaan benda-benda bersejarah cenderung terhalang oleh banyaknya perkembangan bangunanbangunan baru. Oleh karena itu, ketersediaan ruang publik di kawasan pusat kota sangat diperlukan untuk mendukung pelestarian aset-aset bersejarah kota. Ruang terbuka publik merupakan sarana yang tepat untuk dijadikan sebagai tempat atau ruang penghubung aset-aset bersejarah tersebut.

Kawasan pusat kota Banda Aceh memiliki ruang terbuka strategis yang terletak tepat di tengah-tengah kawasan pusat kota lamanya. Ruang terbuka ini dulunya merupakan bagian dari pola ruang pusat kota kerajaan pada masa Tamaddun Islam yang menjadi cikal bakal perkembangan kota Banda Aceh. Saat ini, ruang terbuka tersebut dipertahankan sebagai salah satu aset pusaka saujana. 


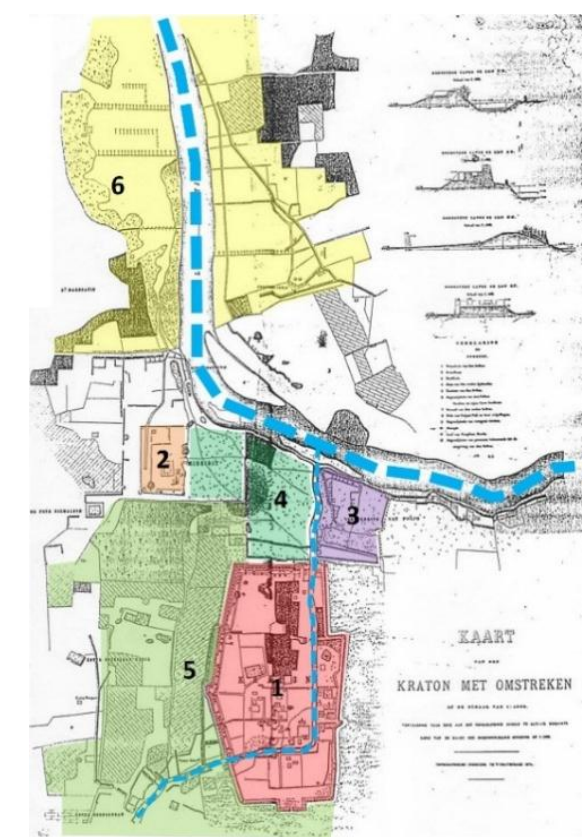

Gambar 2. Pola tatanan ruang kota Banda Aceh pada masa Tamaddun Islam (abad ke17)

Sumber: Peta Kaart van den Kraton Met Omstreken (DC.27.11) KITLV, Leiden

Pola tatanan ruang kota Banda Aceh pada masa Tamaddun Islam terdiri dari Keraton, Masjid Raya, pasar, alun-alun, taman/kebun dan pemukiman (no.1-6). Elemen sungai juga menjadi suatu elemen yang penting pada pola ruang ini, karena kala itu sungai merupakan jalur transportasi utama kota. Kota Banda Aceh telah mengalami beberapa periodisasi masa perkembangan kota, yaitu dimulai dari masa Tamaddun Islam, kemudian berlanjut ke masa kolonial, masa kemerdekaan serta masa setelah tsunami. Periodisasi masa ini membentuk image atau citra kota tersendiri bagi Banda Aceh antara lain citra Banda Aceh, Kutaraja, Serambi Mekkah, Darussalam dan Aceh Lhee Sagoe. Potensi sejarah kota Banda Aceh perlu dipertahankan dan ditingkatkan pada kawasan pusat kota, khususnya pada area ruang-ruang publiknya.
Saat ini, ruang terbuka publik di tengah kawasan pusat kota terdiri dari fungsifungsi yang beragam, antara lain area pasar, pertokoan, perkantoran, masjid, dan taman. Gambar kawasan pusat Kota Banda Aceh di bawah ini (Gambar 3) memperlihatkan ragam fungsi ruang publik yang terdapat pada jalur koridor tersebut. Titik nomor 1 adalah jembatan Peunayong yang dibangun pada masa kolonial, nomor 2 adalah sungai Krueng Aceh, nomor 3 adalah bantaran sungai yang digunakan sebagai area pertokoan, nomor 4 adalah area Masjid Raya yang merupakan inti dari titik bersejarah yang terdapat pada area ini. Titik nomor 5 adalah Taman Sari, suatu peninggalan masa kolonial, serta nomor 6 adalah Taman Putroe Phang yang merupakan taman peninggalan masa Tamaddun Islam. Area-area ini diklasifikasilan ke dalam tiga karakter ruang yang berbeda, yaitu zona Sungai, zona masjid dan zona taman.

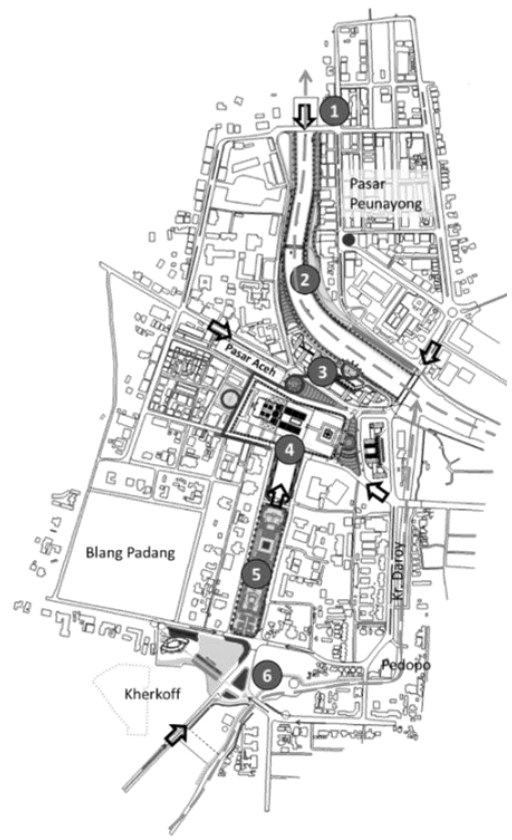

Gambar 3. Objek studi kaoridor publik kawasan pusat kota Banda Aceh

Sumber: Ilustrasi pribadi tahun 2017 
Teknik-teknik perancangan tatanan ruang kota, tidak terlepas dari prinsipprinsip penyusunan (ordering principle), seperti sumbu, simetri, hirarki, irama, datum, pengulangan dan transformasi (Ching 2007). Tatanan merujuk tidak hanya pada keteraturan geometris saja, tapi lebih pada suatu kondisi dan setiap bagian dari suatu keseluruhan ditempatkan secara pantas melalui rujukan pada bagian-bagian lain yang tujuannya agar bisa menghasilkan suatu tatanan yang harmonis. Aspek-aspek yang visual dapat ditinjau dari rupa dan tampaknya, yakni elemen bentuk, warna, karakter spasial, skala, tekstur dan garis. Dalam urban design, beberapa konsep dasar untuk mendesain ruang kota antara lain adanya susunan (order), kesatuan, proporsi, skala, harmoni, simetri, keseimbangan, ritme dan kontras. Biasanya, kecermatan dalam pengolahan bentuk tatanan ruang kota yang dikemas dengan artikulasi arsitektural yang tepat dapat memunculkan aksen-aksen visual menarik, seperti vista, skyline, pattern, dan pola pencahayaan ruang yang dapat mengangkat eksistensi elemen-elemen ruang yang ada di dalam kawasan tersebut.

\section{Fungsi Ruang Terbuka Publik}

Ruang publik dalam lingkungan kota merupakan lokasi yang paling sesuai untuk menunjukkan karakter serta identitas kota tersebut. Ruang publik di kawasan pusat kota dapat berupa taman, alun-alun, plaza, pedestrian dan pasar terbuka. Ruang publik merupakan ruang yang digunakan manusia untuk melakukan interaksi sosial, bermain, dan melakukan kegiatan publik secara bersama-sama. Keberadaan ruang publik di lingkungan kota dapat memberikan dampak positif dalam berbagai aspek kehidupan kota, diantaranya, ruang publik dapat memperbaiki kualitas iklim mikro pada suatu kawasan, ia juga dapat mendorong masyarakat untuk melakukan interaksi sosial, dari segi ekonomi, ruang publik dapat memberikan dampak positif, yakni menampilkan kualitas ruang yang baik sebagai daya tarik suatu area komersial.

Gehl (1987) mengungkapkan dalam penilitiannya bahwa ruang luar/ ruang publik dengan desain yang baik akan lebih banyak diminati publik untuk digunakan melakukan aktivitas-aktivitas pilihan seperti berjalan-jalan, menikmati ruang luar, melakukan kegiatan festival, bersosialisasi dan lain-lain. Cullen (1971) juga mengungkapkan suatu penelitian yang menarik bahwa pergerakan dalam ruang kota, melihat pelbagai karya arsitektur secara kolektif, menemukan keunikan-keunikan ruang dan lain-lain dapat melahirkan suatu emosi atau respon tertentu bagi pengamatnya. Reaksi manusiawi ini merupakan hal yang penting di dalam sebuah kota untuk membangkitkan rasa keterikatan dengan kota atau kawasan tersebut.

Pada kawasan kota bersejarah, nilai-nilai sejarah suatu kota merupakan potensi yang sangat penting untuk memberikan karakter pada sebuah suasana ruang. Salah satu cara untuk mengemas keunikan kawasan kota bersejarah dapat dilakukan dengan menghadirkan tampilan ruang-ruang publik yang menarik dan unik, antara lain dengan memberikan penekanan-penekanan visual pada desain ruangnya, dengan tujuan memperkuat eksistensi nilai-nilai bersejarah yang ada pada lokasi tersebut. Ketersediaan ruang-ruang publik yang menarik dapat mendorong manusia untuk lebih aktif menggunakan ruang- 
ruang publik sebagai ruang beraktivitas sehari-hari, seperti bersosialisasi, bermain, relaksasi atau sekadar menikmati ruang luar di kawasan bersejarah tersebut.

Penelusuran koridor publik dimulai dari zona Sungai, yaitu area jembatan Peunayong. Dari posisi ini, Menara Masjid Raya sudah dapat terlihat dari kejauhan, disebabkan oleh dimensi sungai yang cukup lebar sehingga memungkinkan untuk menciptakan pandangan langsung ke arah area Masjid Raya tanpa terhalang oleh bangunan atau elemen ruang lainnya. Kondisi ini merupakan tampilan visual yang cukup baik untuk memberikan arah dan orientasi dalam memahami ruang.
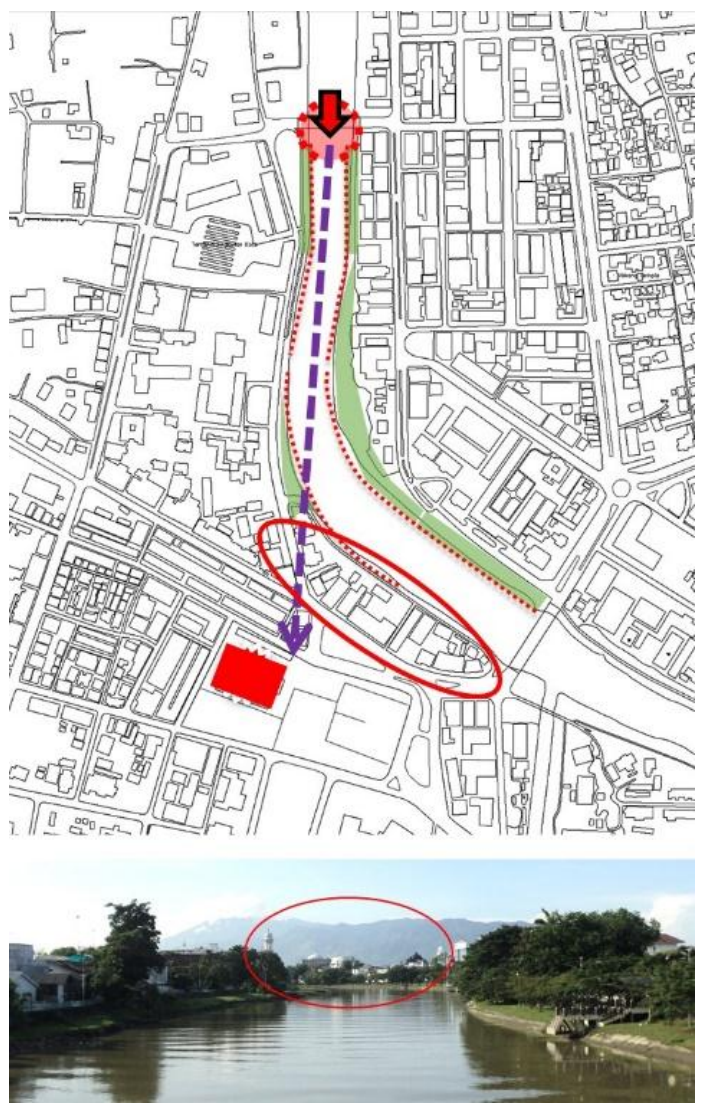

Gambar 4. Tampilan masjid dari arah jembatan peunayong

Sumber: Dok. Pribadi, tahun 2015
Pencapaian publik dari jembatan Peunayong ke masjid Raya didominasi oleh jalur jalan raya. Sementara penggunaan pedestrian tidak begitu populer pada area ini, karena area bantaran sungai merupakan area yang pasif dari kegiatan publik.

Pemerintah kota telah beberapa kali melakukan penataan lansekap pada area bantaran sungai ini, antara lain dengan membuat pedestrian lengkap dengan lampu dan pagar pembatas serta pembuatan area taman di bantaran sungai, namun hal ini belum berhasil membuat area sungai menjadi lebih hidup sebagai ruang publik.

Zonasi kedua adalah zona masjid. Pada area ini sosok Masjid Raya tampil dengan megah di antara bangunan dan jalan raya. Area Masjid Raya dikelilingi oleh jalan raya arteri yang lebar. Kondisi eksisting yang ada memperlihatkan aksesibilitas untuk mencapai ruangruang ini didominasi oleh jalur kendaraan bermotor. Bangunan di sekeliling Masjid Raya memiliki bentuk dan rupa yang berbeda-beda, namun masih pada besaran bangunan yang relatif sama, yakni bertingkat dua atau tiga lantai.

Kawasan Masjid Raya ini merupakan area yang paling sering dikembangkan. Mulai dari pengembangan fisik bangunan Masjid Raya, hingga ke area halaman masjidnya. Namun, pengembangan diluar area pagar masjid raya belum terlalu banyak diolah, sehingga area di sekitar Masjid Raya ini masih perlu ditingkatkan kualitasnya khususnya untuk mengakomodasi kebutuhan para pejalan kaki.

Zonasi ketiga adalah zona taman yang memiliki karakter ruang yang tidak terlalu ramai, namun berfungsi sebagai ruang publik dengan baik. Fungsi ruang 
di sekitar taman didominasi oleh fungsi bangunan perkantoran. Bentuk lahan taman sari berupa persegi panjang. Bentuk demikian secara otomatis memberikan orientasi dan arah ke zona Masjid Raya. Kondisi saat ini, di dalam taman sari ini dibangun beberapa bangunan yaitu perpustakaan, bangunan gerbang entrance dan tugu proklamasi. Permasalahan hubungan ruang antara zona taman dan zona Masjid adalah jarak yang cukup panjang, sehingga dibutuhkan aksentuasi visual untuk memecah kemonotonan tampilan ruang di area taman.

Ditinjau dari bentuk morfologisnya, kota Banda Aceh terdiri dari campuran konfigurasi bentuk yaitu konfigurasi grid dan organik. Hal ini membuat tampilan struktur kawasan kota cenderung rumit dan tak beraturan. Koridor publik dapat berfungsi sebagai pemersatu kondisi morfologis ini, dengan memberi penekanan aksentuasi visual secara keseluruhan sekaligus membentuk karakter ruang bersejarah. Pada skala ini, koridor ruang publik telah menjadi suatu aksentuasi visual bagi kawasan pusat kota. Kesinambungan koridor ini dapat dicapai dengan membuat jalur pedestrian yang menerus. (Gambar 5 \& 6)

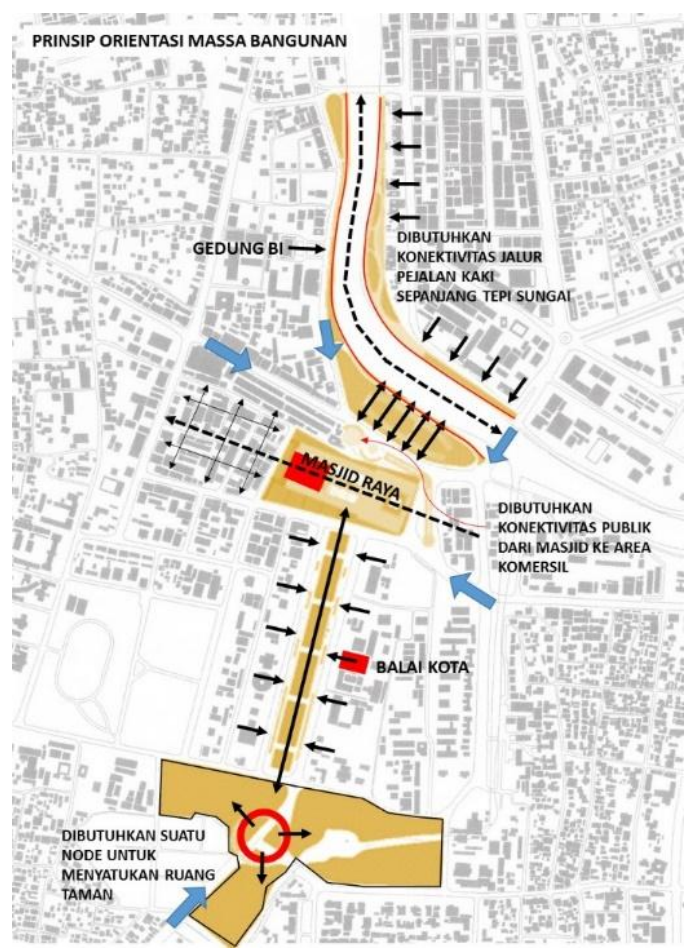

Gambar 5. Prinsip penataan orientasi bangunan di sekitar koridor ruang publik

Sumber: ilustrasi pribadi di tahun 2017

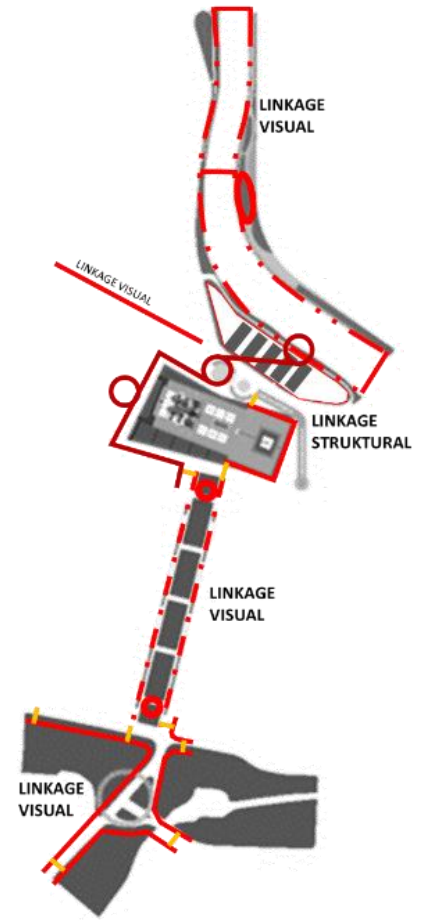

Gambar 6. Prinsip desain linkage koridor ruang publik

Sumber: Ilustrasi pribadi di tahun 2017 
Sebagai sebuah pusat kota bersejarah, keberadaan ruang publik yang menarik dapat menarik minat masyarakat untuk melakukan aktivitas pilihan selain dari hanya sekedar melintas di ruang tersebut. Menurut Carmona (2012), bahwa ruang publik di kawasan pusat kota hendaknya memiliki kualitas fisik yang simbolik, publik, inklusif, dapat beradaptasi dan berkualitas tinggi, karena kawasan ini merupakan wajah utama bagi kota secara keseluruhan. Dengan membuat ruang publik berkualitas di lokasi ini, diharapkan masyarakat kota dapat lebih banyak memanfaatkannya sebagai sarana rekreasi dan sosial warga untuk membentuk keterikatan sosial antar masyarakat kotanya, serta mengangkat eksistensi nilai-nilai sejarah kotanya.

\section{Koneksivitas antar ruang-ruang bersejarah}

Kawasan kota merupakan suatu tempat yang kompleks dan rumit. Perkembangan kota sering mempunyai kecenderungan membuat orang merasa tersesat di daerah kota yang belum mereka kenal. Untuk itu, elemen-elemen linkage dibutuhkan untuk membantu orang dalam memahami bagian-bagian kota sebagai bagian dari suatu keseluruhan yang lebih besar. (Zahnd 1999) Terlebih lagi apabila teori linkage diterapkan pada kawasan yang memiliki nilai sejarah, maka eksistensi identitas kota dapat semakin ditonjolkan dalam lingkungan kota, yakni dengan adanya hubungan antar ruang tersebut.

Dalam teori linkage, ruang-ruang di dalam ruang kota dapat dihubungkan dengan beberapa metode, antara lain secara visual, struktural maupun kolektif. Linkage visual adalah dengan memberikan hubungan visual antar dua titik/ tempat melalui elemen-elemen visual, seperti deretan pohon, lampu dan lain-lain. Linkage struktural adalah dengan menghubungkan dua daerah dengan elemen-elemen struktural (tambahan, sambungan dan tembusan). Kemudian linkage kolektif merupakan suatu gubahan bentuk kompleks yang memiliki kesatuan rupa bentuk. Linkage kolektif dapat dikenali dalan tiga tipe, yaitu komposisi, bentuk grup dan bentuk megaform. (Zahnd 1999) (Gambar 7)

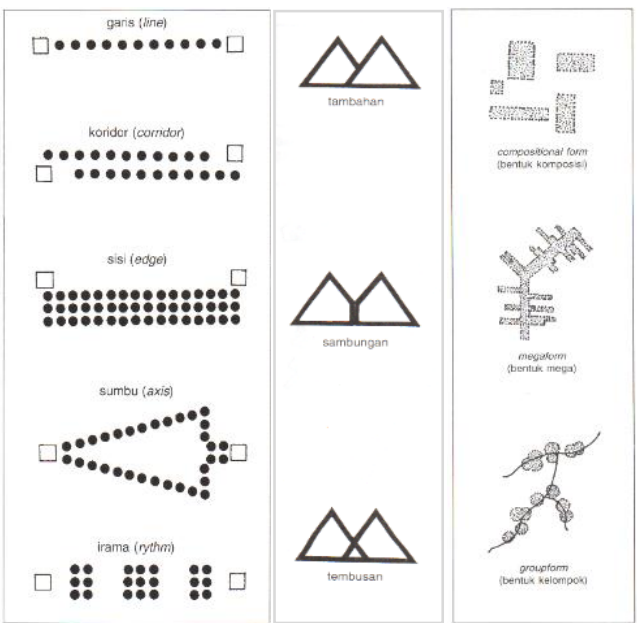

Gambar 7. Teknik-teknik penghubung ruang di kawasan kota

Sumber: Zahnd (1999)

Perancangan ruang dalam konteks kota tidak cukup hanya dengan mengacu pada teori linkage saja, melainkan perlu di dukung dengan teori lainnya yaitu figure-ground dan teori place (Trancik,1986). Ketiga teori perlu dikombinasikan saat menelaah suatu kawasan kota.

Pada contoh kasus di zona sungai, hubungan visual antara objek Masjid Raya dan Sungai Kr.Aceh merupakan sebuah kondisi visual yang diharapkan dapat memperkuat citra kawasan pusat Kota Banda Aceh sebagai kota air yang bersambung dengan zona Masjid 
sebagai simbol dari kota Sermbi Mekkah.

Ditinjau dari kondisi tapaknya, dengan memperhatikan hubungan solid dan void area ini, pandangan langsung ke arah Masjid Raya tidak terjadi karena terhalangi oleh deretan bangunan pertokoan yang masif.
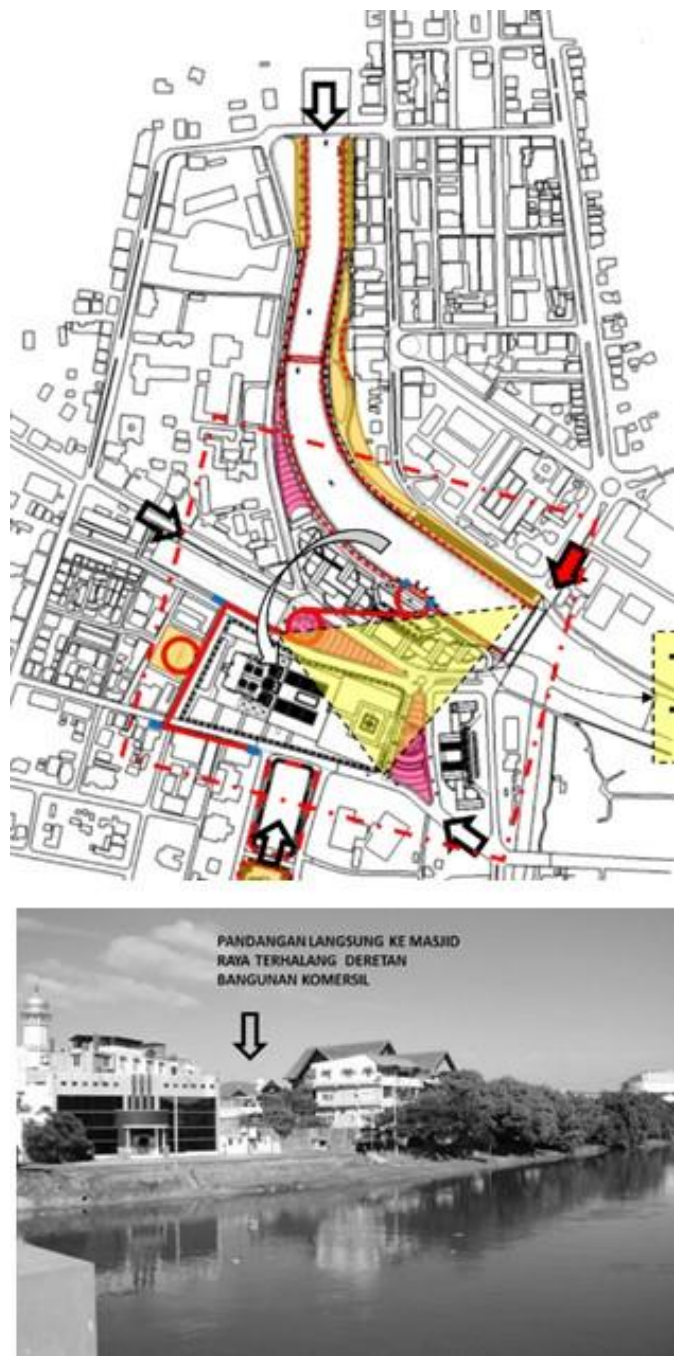

Gambar 8. Hubungan visual antara masjid dan sungai dari jarak dekat

Sumber: Dok. Pribadi, tahun 2017

Peningkatan hubungan visual ke arah Masjid Raya, dapat dilakukan dengan membuat penataan pada komposisi massa bangunan tersebut, agar tercipta hubungan visual antara keduanya. Misalnya dengan mengurangi area terbangun pada lahan ini, serta mengkombinasikannya dengan ruang terbuka hijau/ruang publik, atau menetapkan ketinggian maksimal yang diperbolehkan untuk dibangun pada area itu, atau pemilihan material bangunan yang transparan.

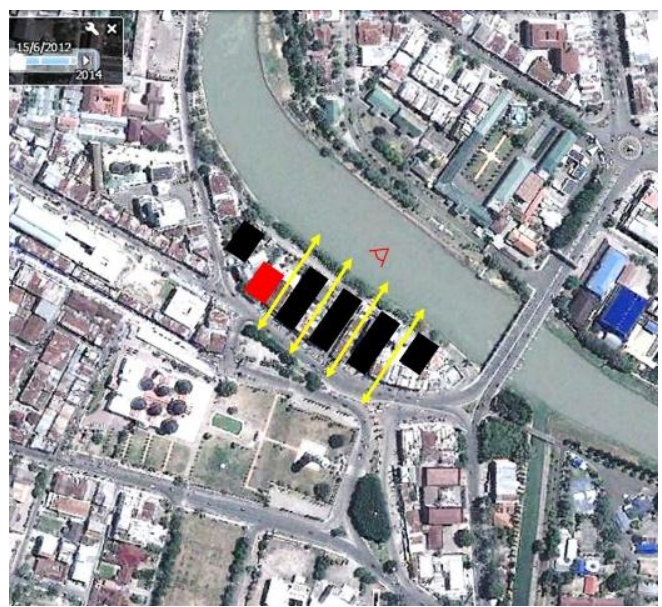

Gambar 9. Prinsip desain hubungan visual dari sungai ke arah masjid raya

Sumber: Dok. Pribadi, tahun 2017

Untuk memperkuat elemen sungai sebagai penghubung ke arah Masjid, salah satu cara yang dapat dilakukan adalah dengan memberikan elemenelemen tambahan pada bagian tepi sungai baik di sebelah kanan dan sebelah kiri, berupa jalur promenade yang menarik, deretan pohon atau lampu, bangku-bangku serta elemen-elemen visual lain yang secara konsisten dipasang untuk menuntun pandangan mata menuju objek Masjid Raya.

Pada kasus kedua yakni zona taman, hubungan antar ruang dari titik taman Putroe Phang menuju Masjid Raya disambungkan oleh sebidang lahan terbuka berupa area taman sari. Tersambungnya kedua zona ruang ini akan memperkuat identitas dan 
pemaknaan ruang kota Banda Aceh sebagai kota serambi Mekkah yang bernuansa islami yang terhubung dengan citra Darussalam.

Berbeda dengan kasus yang pertama, zona taman sari merupakan area publik yang cukup ramai. Hal ini didukung oleh deretan bangunan fungsional yang terdapat di bagian kanan dan kiri taman. Lahan taman sari berbentuk persegi panjang atau linier. Bentuk linier memiliki sifat yang dinamis termasuk mengarahkan sirkulasi dari satu titik ke titik lain.

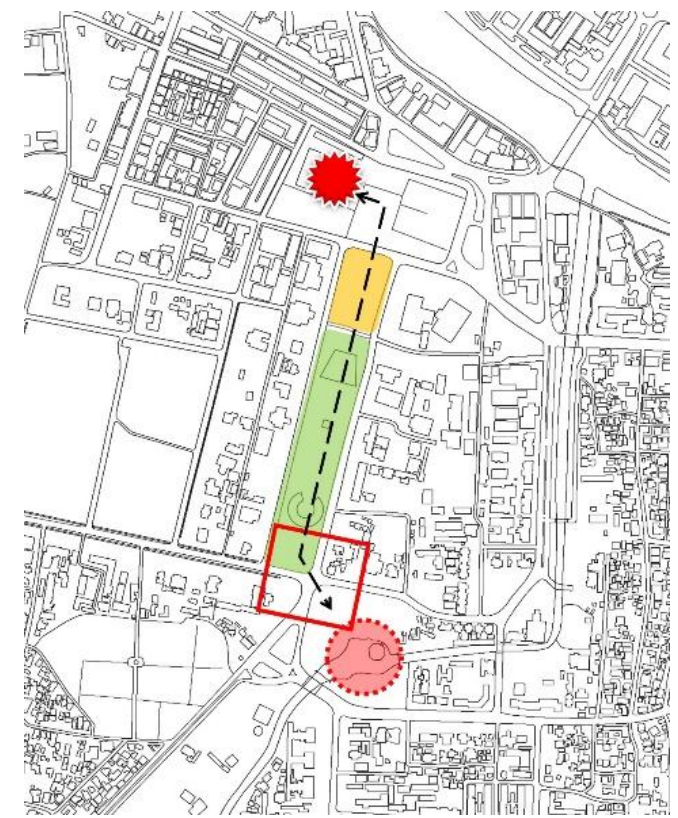

Gambar 10. Hubungan ruang antara masjid dan taman

Sumber: Dok. Pribadi, tahun 2017

Pada bagian tengah area taman, terdapat bangunan-bangunan baru yang menghalangi pandangan langsung ke arah zona masjid. Keberadaan bangunan-bangunan di tengah ruang taman dipandang dapat mengurangi koneksivitas pandangan ke arah titik tujuan. Maka untuk tetap dapat memberi kesan mengarahkan ke titik tujuan, desain elemen pedestrian dengan pola dan motif yang relevan dapat menjadi solusi desain pada ruang ini.

Penerapan aksentuasi visual pada skala ruang setempat (place) tidak hanya sekedar membuat area ruang menjadi lebih cantik, namun yang lebih penting adalah perkuatan dari nilai-nilai sejarah pada area tersebut. Ketiga zona memiliki karakter ruang yang berbeda. Pada zona sungai, karakter kota Banda Aceh sebagai kota air dapat muncul apabila terdapat perahu-perahu yang meramaikan aliran sungai, maka penyediaan sarana dermaga dapat menjadi pilihan dalam aksentuasi visual pada area ini.

Pada zona masjid, elemen pedestrian dapat dibentuk berupa selasar dengan tiang-tiang arch yang menyerupai salah satu elemen dari kolom Masjid. Pada zona taman, ruang taman diberi penekanan desain dengan mengutamakan konsep darussalam yang tenang, dengan mengkombinasikan tiga elemen lansekap utama yaitu penataan vegetasi, elemen air dan jalur pedestriannya.

\section{Kesimpulan}

Konteks kawasan pusat kota Banda Aceh memiliki karakter ruang yang khas, yaitu dari sisi potensi sejarah dan kondisi alam naturalnya. Kedua hal ini merupakan ciri khas utama kota yang perlu diprioritaskan dalam rangka upaya peningkatan identitas kota Banda Aceh. Penelitian mengenai kawasan pusat kota ini merupakan penelitian ruang yang cukup kompleks. Kawasan kota perlu dipahami tidak hanya secara dua dimensi tetapi juga secara tiga dimensi. Aksentuasi visualnya dapat dikenali dengan memperhatikan bentuk 
morfologi ruang kawasan tersebut, yang terbagi dalam tiga fase ruang, yakni skala kawasan, hubungan antar dua buah ruang dan ruang setempat.

Aksentuasi visual pada skala kawasan ditentukan oleh struktur atau pola ruang yang dominan pada kondisi morfologi kawasan kota. Elemen ruang yang dapat dirancang antara lain pola jalur pedestrian dan pola perletakan vegetasi. Penetapan batasan koridor publik merupakan suatu aksentuasi visual pada skala masterplan ini yang membedakan dengan ruang-ruang terbuka lain di luar kawasan pusat kota Banda Aceh. Pada tahap ini, elemen pedestrian dan vegetasi berfungsi sebagai elemen utama perangkai aset-aset bersejarah dalam koridor publik yang juga sesuai dengan salah satu citra kota Banda Aceh yaitu sebagai kota Darussalam.

Aksentuasi visual pada fase hubungan antar ruang, ditentukan oleh penataan massa bangunan dan elemen-elemen pembentuk ruang lainnya (mis. pohon, lampu, street furniture, dll) di masingmasing zona kawasan. Pada tahap ini, eksistensi ruang bersejarah menjadi penting sebagai titik berangkat (origin) dan titik tujuan (destinasi) untuk menentukan pilihan konfigurasi massa yang sesuai dengan konteks ruangnya. Aksentuasi visual dapat dilihat pada bentukan ruang secara tipologis. Pada contoh dua kasus yang dibahas pada penelitian ini, bentuk ruang linier dapat dihubungkan dengan membuat deretanderetan elemen ruang. Sementara pada tipologi ruang terpusat penyelesaian desainnya perlu ditempuh dengan mengolah ruang secara struktural sehingga memperoleh suatu enclosure ruang yang diharapkan.

Aksentuasi visual pada ruang setempat (node) ditentukan dengan material, tekstur, warna dan bentuk pada elemenelemen di ruang publik yang relevan dengan karakter sejarah ruang tersebut. Biasanya desain pada fase ini berupa penekanan-penekanan tertentu pada elemen-elemen penting yang perlu ditonjolkan, misalnya dengan membuat pelataran, pilihan bentuk atau papan penanda yang berisi informasi tertulis mengenai sejarah ruang tersebut.

Gabungan dari ketiga fase ini dapat meningkatkan kualitas visual pada kawasan pusat kota menjadi lebih jelas dan menarik. Ketersediaan ruang publik yang terhubung secara menerus melalui pedestrian dapat mendukung tampilan aksentuasi visual kawasan kota bersejarah menjadi suatu serial pengalaman ruang yang khas dan mudah untuk ditelusuri dan dipahami.

\section{Daftar Pustaka}

Arif, Kamal A. 2008. Ragam Citra Kota Banda Aceh: Interpretasi Sejarah, Memori Kolektif dan Arketipe Arsitekturnya. Bandung: Pustaka Yayasan Bustanussalatin.

Ashihara, Yoshinobu. 1970. Exterior Design in Architecture, Van Nostrand Reinhold.

Carmona, Matthew. 2012. Capital Spaces 2012. A Design Guide For London's Public Spaces. https://www.ucl.ac.uk/london2062/documents/capital_spaces (diakses 11 Mei 2017)

Cullen, Gordon. 1971. The Concise Townscape. second edition. Architectural Press, London.

Gehl, Jan. 1987. Life between buildings. Van Nostrand Reinhold Company, New York. 
Hakim, Rustam dan Hardi Utomo. 2003. Komponen Perancangan Arsitektur Lansekap. Prinsip- Unsur dan Aplikasi Desain, PT. Bumi Aksara: Jakarta

Shirvani, Hamid. 1985. Urban Design Process. New York: Van Nostrand Reinhold.

Trancik, Roger. 1986. Finding Lost Space. New York: Van Nostrand Reinhold.

Zahnd, Markus. 1999. Perancangan Kota Secara Terpadu. Yogyakarta: Kanisius. 
Jurnal Teknik Arsitektur ARTEKS, Volume. 2, Nomor 1, Desember 2017 ISSN 2541-0598 